\title{
EARLY GEOBIOCHEMICAL EVOLUTION OF THE EARTH
}

\author{
I.B. LAMBERT*
}

\begin{abstract}
Important constraints on the nature of the early lithosphere come from estimated temperatures in the Earth during accretion/core formation, and experimental rock melting studies. For minimum and maximum temperature estimates, only a thin outer zone would have melted and cooling and fractionation should have produced a predominantly mafic proto-crust grading down into olivine-rich cumulates and depleted peridotitic mantle; the volume of granitic rock produced would have been much smaller than in the present crust. As a consequence of high geothermal gradients, and the impacting of giant projectiles pre-3.9 Ga, ultramafic to felsic igneous rocks, and exhalative sedimentary strata, would have been added to protocrust through the pre-Archean (Hadean). The main processes involved in transformation from a predominantly mafic proto-crust to a granite-rich crust were partial melting in the primitive lithosphere and sinking of dense residual mafic crust as geothermal gradients decreased.

Recent stable isotope studies, together with various geological features, imply: 1) the Archean hydrosphere was probably warmer, less saline, and contained relatively high proportions of juvenile components; 2) photosynthesis was established locally by $3.5 \mathrm{Ga}$, the age of the oldest widely accepted microfossils, but bacterial sulfate reduction was not a significant process until $\leq 2.8 \mathrm{Ga}$; 3) sulfate was not generally abundant in the Archaean hydrosphere and hence, the atmosphere of this era is very unlikely to have been oxygenated.
\end{abstract}

INTRODUCTION In recent years, there has been a proliferation of studies aimed at constraining interpretation of the processes involved in the formation and early evolution of the Earth. Relevant data have come from a wide variety of field and laboratory based investigations of ancient terrains, experimental petrological studies, geophysical calculations, microbiological and astronomical considerations (cf. reviews by Lambert and Groves, 1981; McCall, 1981).

This paper considers aspects of the early geobiochemical evolution of the Earth, integrating data available from these diverse sources. It amplifies and updates a number of the conclusions reached by Lambert and Groves (1981). The first section covers the formation of the primordial crust and the changes it underwent during the Archean. The next section considers the early hydrosphere/atmosphere system, and the third speculates about the evolution of life on Earth.

\section{PRIMITIVE LITHOSPHERE Thermal regime in} newly formed Earth Core formation must have occurred during, or within a few hundred million years after accretion of the Earth (Oversby and Ringwood, 1971; Ringwood, 1977a, 1979; Vollmer, 1977). Heating during accretion/core formation would have caused melting, and the primordial crust would have formed as cooling by convection and surface radiation led to solidification of the melt. There are no known relics of this early lithosphere, so its nature has to be deduced from considerations of estimated thermal gradients and experimental petrological data. It will be shown below that these lines of evidence imply that only a thin outer zone of the Earth would have been melted, contrary to some earlier suppositions of a largely or wholly molten Earth (e.g. Shaw, 1972, 1976).

The thermal effects of core segregation have been assessed by Ringwood $(1977 a, b ; 1979)$. He concluded that if this process took a million years or more, the temperatures in the mantle would not be much different from those generat- ed by accretion; in the outer Earth these temperatures are likely to have been no greater than $1600^{\circ} \mathrm{C}$ (Fig. 1; Ringwood, op. cit.; Hanks and Anderson, 1969). For catastrophic formation of the core, in a period of around a thousand years, temperatures should have been elevated to around $2,000^{\circ} \mathrm{C}$ near the surface and $3,500^{\circ} \mathrm{C}$ at the mantle-core boundary (Fig. 1).

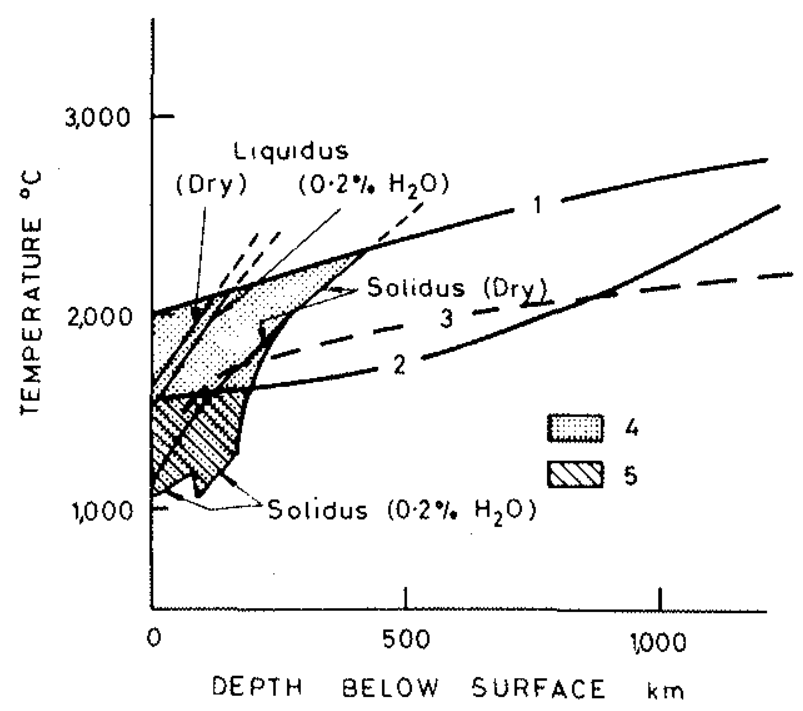

Figure 1-Beginning of melting (solidus) curves and complete melting (liquidus) curves for peridotitic mantle and estimated temperature distributions in the early Earth (adapted from Ringwood 1975, 1977a, 1979). $1=$ Maximum temperature distribution post core formation (adiabat); $\mathbf{2}=$ post-accretion temperature distribution, which approximates minimum possible temperature distribution following core formation; 3 =temperature distribution in newly accreted Earth, after Hanks and Anderson (1969); $4=$ zone of melting after catastrophic core formation; $\mathbf{5}=$ zone of melting for core formation at a time scale of $10^{6}$ years 
Salient experimental data on rock melting To assess the degree of melting of the Earth, the estimates of minimum and maximum temperatures have to be considered in the light of experimentally determined melting reactions for mantle peridotite. It is apparent from Fig. 1 hat the lowest and highest estimated thermal gradients both move out of the zone of melting at shallow mantle depths. The minimum gradient would have caused partial melting to a depth of only $120 \mathrm{~km}$ or so under dry conditions, or around $200 \mathrm{~km}$ if there was a minor amount of water present. The maximum gradient would have caused complete melting to depths of around $120 \mathrm{~km}$, and partial melting from there to around $400 \mathrm{~km}$, under wet or dry conditions (Fig. 1).

In considering the products of the outer Earth melting, it is necessary to take account of the following conclusions from experimental studies (cf. reviews by Wyllie, 1971; Nicholls and Ringwood, 1972; Ringwood, 1975; Green, $1976 a, b)$ :

(i) Partial melting of peridotite under a wide range of conditions yields basaltic magmas; ultramafic melts require very high degrees of melting, or sequential melting of peridotitic source rock.

(ii) Magmas of intermediate (basaltic andesite) composition can form directly from peridotite by wet melting only at pressures $<10 \mathrm{kbar}$ (depths of $<30 \mathrm{~km}$ ). Mysen and Boettcher (1972) reported andesitic glasses in experiments with hydrous peridotite at $20 \mathrm{kbar}$, but Nicholls and Ringwood (1974) argued that these quenched from the vapour phase and are much more silicic than melts produced under these conditions.

(iii) Silicic magmas $\left(>60 \% \mathrm{SiO}_{2}\right)$ cannot be the direct melting product of peridotite, or the fractionation product of peridotitic liquids, but they can form by partial melting of basic to intermediate rocks in the crust ; they can also form in minor proportions by high-level fractionation of mafic melts, as evidenced by the granophyre components of large layered mafic intrusives and by uncommon plagioclase granitoids in oceanic crust.

\section{Composition of primitive crust and upper mantle}

The above constraints imply that the main products of fractional crystallisation of melts produced in the outer Earth by both the minimum and maximum thermal gradients in Fig. 1, would have been ultramafic cumulates and mafic rocks, with the former beneath the latter in general. The constraints on the formation of granitic and anorthositic rocks from a peridotite source imply that the volume of sialic rocks in the first-formed crust must have been considerably less than in the present continental crust: if the primordial granitic material accumulated in a surficial layer, this layer could not have been more than $2-3 \mathrm{~km}$ thick. Mafic rocks would have formed a crust extending to roughly $30 \mathrm{~km}$ for the lowest temperature estimate, and $100 \mathrm{~km}$ for the highest temperatures. Beneath this should have been ultramafic cumulates and depleted peridotitic mantle, probably with entrapped melt, overlying unmelted mantle peridotite.

It is likely that mega-impact events markedly influenced the early $(>3.9 \mathrm{Ga}$ ) evolution of the outer regions of the Earth (e.g. Green, 1972; Glikson, 1976; Goodwin, 1976; Smith, 1976), causing major brecciation and fracturing, melting, degassing and addition of significant amounts of material from planetesimal bodies. Mafic and ultramafic melts should have ascended from the mantle, whilst partial melting of mafic crust and high level fractionation of mafic melts should have generated granitic components, and degassing should have yielded exhalative sediments in addition to adding components to the atmosphere.

\section{ASPECTS OF ARCHEAN CRUST-MANTLE EVO- LUTION Early Archean crust The oldest well-} -documented Archean terrain, in the North Atlantic Craton, formed 3.65-3.8 Ga ago (e.g. Moorbath et al, 1977; Hamilton et al., 1978; O'Nions and Pankhurst, 1978). This ancient crust comprises mainly gneisses formed by deformation of intrusive tonalitic to granodioritic rocks (e.g. McGregor, 1973). These intrude metamorphosed and deformed supracrustals (Allaart, 1976) comprising rocks which appear to have been originally ultramafic to felsic volcanics and intrusives, and sedimentary strata with major exhalative components. Evidently the surface had cooled sufficiently by $3.8 \mathrm{Ga}$ for accumulation of liquid water.

Available evidence strongly implies that the amount of granite in the earliest Archean crust was still much less than in the present crust. Whilst there are some examples of reworking of the ancient sialic rocks in the North Atlantic Craton during younger thermal events (e.g. Collerson et al., 1981 ), the least contrived interpretation of most of the radiometric age and initial ratio data world-wide is that major volumes of granitic material were added to the crust through the Archean (e.g. O'Nions and Pankhurst, 1978). Commonly, greenstone sequences yield ages slightly older than spatially associated granitoids, implying that mantle melting episodes led to crustal anatexis. Major addition of sialic material to the crust during the Archean is further evidenced by rare earth element (REE) patterns (Taylor and McLennan, 1981) and other geochemical features (Cameron and Garrels, 1980) of sedimentary rocks of that era, which indicate more mafic sources than for post-Archean sediments.

Based on regional metamorphic grades in thick greenstone sequences, average thermal gradients in the Archean are unlikely to have exceeded $40^{\circ} \mathrm{C} / \mathrm{km}$ (Glikson and Lambert, 1976).

Generation of ultramafic lavas Green (1972) concluded that Archean quench-textured ultramafic volcanics formed by very high degrees of melting (up to $80 \%$ ) of mantle peridotite, with rapid upwelling of the little fractioned melt and extrusion temperatures of at least $1600^{\circ} \mathrm{C}$. This would require melting of superheated mantle rising adiabatically from considerable depths. Impact events are unlikely to have been the main triggering mechanism for komatiite generation, as proposed by Green (op. cit.), in view of the abundance of high-Mg peridotite lavas in late Archean sequences.

Generation of ultramafic melts by smaller degrees of partial melting of residues from previous mantle melting events has been suggested from considerations of melt viscosities and crystal settling velocities (Arndt, 1977), and from geochemical features of komatiites, particularly the light REE depletions in many of them (Arth et al., 1977; Bickle et al., 1976; Sun and Nesbitt, 1978). Arndt (op. cit.) envisaged that about $20 \%$ melting in ascending mantle diapirs produced (low-Mg) olivine tholeiite magmas. These separated from the diapirs which continued to rise, melting 
at a reduced rate until a second batch of magma separated, this being of high- $\mathrm{Mg}$ basaltic composition. Continuation of the ascent and melting process would ultimately lead to formation of magmas of komatiitic peridotite composition by relatively low degrees of melting of crystalline residue enriched in refractory components.

The conclusion was reached above that outer Earth melting generated olivine-rich cumulates and depleted peridotite in the upper mantle. These could have yielded komatiitic magmas by less protracted sequential melting than underlying, undepleted peridotite. Another important feature of the upper mantle could have been a magma-mantle density inversion, beneath which the density of the relatively compressible melt exceeded that of the crystal residue (N. Arndt and E. Nisbet, per. comm., 1982). This could have constrained high proportions of melt within ascending diapirs until they ascended above the density inversion depth.

Variations in the chemistry of komatiitic volcanics probably reflect the depths from which the mantle diapirs ascended, and high-level fractionation processes. The deeper source should have been undepleted, garnetiferous peridotite, which could have generated komatiites with high $\mathrm{Ca} / \mathrm{Al}$ and heavy REE depletions, like the predominant type in the $c a .3 .6 \mathrm{Ga}$ Barberton greenstone sequence (e.g. Sun and Nesbitt, 1978; A. Glikson, per. comm., 1982). Melts generated largely from cumulates and depleted peridotite in the upper mantle should have had lower $\mathrm{Ca} / \mathrm{Al}$ and light REE depletions like a minority of the Barberton komatiites and many younger komatiites elsewhere (Sun and Nesbitt, 1978; A. Glikson, per, comm., 1982).

Generation of granitoids There would have been considerable melting of the primordial, simatic crust, particularly as a result of ascent of hot mantle material. Tonalitic and trondhjemitic magmas would have been the major products (e.g. Lambert and Wyllie, 1972; Glikson and Lambert, 1976), in accord with the abundance of intrusives and gneisses of such compositions in Archean shields. Further destruction of primordial simatic crust probably occurred by ultimate sinking of dense residual rocks from the extensive partial melting events.

The Archean K-rich granitoids, generally post-date the more plagioclase-rich granitoids, and geochemical and experimental data imply that anatexis of tonalitic-trondhjemitic crust was a major source of the younger granites (Lambert and Wyllie, 1974; Glikson and Lambert, 1976; Condie, 1981).

By the end of the Archean, the transformation to a stable sialic crust appears to have been essentially completed.

\section{EARLY ATMOSPHERE AND HYDROSPHERE}

The origin and evolution of the atmosphere has been considered in numerous publications including Brown (1952), Cloud $(1974,1976)$, Fanale $(1971)$ and Walker $(1976 a, b)$; the hydrosphere has been discussed in particular by Rubey (1951), Holland (1972, 1976), and Veizer et al. (1982).

\section{Composition of primitive atmosphere There are} extreme depletions of non-radiogenic inert gases in the Earth's atmosphere relative to cosmic abundances, indicating that primordial gases were not retained. Mass balance considerations, the abundance of radiogenic argon, and other arguments imply that the atmosphere-hydrosphere system formed largely from juvenile components degassed from the Earth's interior, and was subsequently modified by physical, chemical and biological processes.

Rubey (1951) proposed that degassing has been a continuous or recurrent process which is still occurring. However, Fanale (1971), Walker $(1976 a, b)$ and others argued that degassing was essentially completed at a very early stage in Earth history. The answer is probably closer to the latter viewpoint as the rate of degassing must have been in proportion to the amount of igneous activity and the frequency of major impacts. Furthermore, Taylor (e.g. 1977) concluded from oxygen-deuterium isotope studies on igneous rocks that there has been little degassing of juvenile water in the past 2.5-3.0 Ga.

There are two general schools of thought on the composition of the early atmosphere. The concept of a highly reducing atmosphere received impetus from the classic Miller-Urey synthesis of amino-acids, the building blocks of life, by spark discharges in an atmosphere of $\mathrm{NH}_{3},\left(\mathrm{~N}_{2}\right), \mathrm{CH}_{4}, \mathrm{H}_{2}$ and $\mathrm{H}_{2} \mathrm{O}$ (Miller, 1953). On the other hand, geochemical arguments based on the oxidation state of the Earth's mantle, supported by observations of the compositions of fluid inclusions in mantle materials and modern volcanic gases, strongly imply a less-reduced atmosphere comprising mainly $\mathrm{H}_{2} \mathrm{O}$ and $\mathrm{CO}_{2}$, with lesser $\mathrm{CO}, \mathrm{N}_{2}, \mathrm{H}_{2} \mathrm{~S}, \mathrm{SO}_{2}, \mathrm{HCl}$ and little if any $\mathrm{NH}_{3}$ and $\mathrm{CH}_{4}$. The experiments of Abelson (1966) and Hubbard et al. (1971) imply that amino-acids could also have been synthesised from such an atmosphere. The absence of a juvenile $\mathrm{O}_{2}$ source, and the failure of attempts to synthesise amino-acids abiotically in the presence of $\mathrm{O}_{2}$, strongly imply that this gas was not a stable component of the early atmosphere, but was generated by secondary processes. This point will be taken up again in the section on Archean life.

Composition of Archean hydrosphere Initially, temperatures at the surface of the Earth would have been too high for the existence of liquid water, resulting in a very $\mathrm{H}_{2} \mathrm{O}$-rich atmosphere. However, the presence of surface water by $3.8 \mathrm{Ga}$ is indicated by the evidence for sub-aqueous sedimentation in the Isua supracrustals (e.g. Allaart, 1976) and it has been suggested that hydrosphere development was a prerequisite for preservation of crust (e.g. Costa et al., 1981).

It is likely that the main controls on the chemistry of the Archean hydrosphere were reactions with hot igneous rocks, juvenile additions and seafloor "weathering", with minor input from fluvial systems. Oxygen isotope studies of Archean hydrothermal talc-bearing sediments by Costa $e t$ al. $(1980,1981)$ imply the existence of fluids isotopically similar to modern seawater. This observation, together with the lower $\delta^{18} \mathrm{O}$ values for Archean cherts (e.g. Knauth and Lowe, 1978) and carbonates (e.g. Veizer and Hoefs, 1976), suggests that Archean hydrosphere temperatures were higher, probably around $70^{\circ} \mathrm{C}$ on average.

Dolomite is the dominant carbonate mineral in Precambrian (particularly Proterozoic) sedimentary sequences, in contrast with the predominance of calcite in Phanerozoic strata. Tucker (1982) proposed that petrographic evidence suggests a lot of Precambrian dolomite is primary, and he provided some stable isotopic data which support this contention. The formation of dolomite by direct precipitation or early diagenetic reactions would probably require higher temperatures, higher $\mathrm{Mg} / \mathrm{Ca}$, higher $\mathrm{CO}_{2}$ partial pressures and lower $\mathrm{SO}_{4}^{2-}$ than in most younger carbonate-forming environments. 
Reduced sulfur species were important constituents of Archean exhalations, but in most environments the sulfur was largely precipitated as pyrite and other sulfides. There are local examples of bedded barite in $c a .3 .45 \mathrm{Ga}$ shallow water sedimentary sequences in the North Pole area of the Pilbara Block, Western Australia (e.g. Dunlop, 1978; Lambert et al., 1978), and the Barberton area of South Africa (Perry et al., 1971; Heinrichs and Reimer, 1977). The form of the barite, including interfacial angle measurements, implies that these deposits formed at least partly by baritisation of original evaporitic gypsum (Dunlop, 1978; Dunlop and Groves, 1978). Furthermore, the restricted range of isotope compositions for these barite occurrences $\left(\delta^{34} S\right.$ values concentrated around $\left.+3 \%\right)$, imply that the sulfate formed mainly by surficial oxidation of reduced sulfur (Perry et al., 1971; Lambert et al., 1978), but this does not indicate that the contemporaneous atmosphere was oxygenated because of the various oxygen "sinks" in the hydrosphere atmosphere (cf. Archean life section)

The Big Stubby deposit, though only $40 \mathrm{~km}$ from the North Pole and of similar age, presents an interesting contrast. Big Stubby is a small baritic-sulfide body with geological, mineralogical and textural features resembling those of Kuroko-type volcanogenic deposits; it has $\delta^{34} \mathrm{~S}$ values averaging $+12 \%$ and $-3 \%$ for barite and sulfides, respectively (Lambert et al., 1978). These features are consistent with its precipitation from sulfate-bearing waters of the type which gave rise to the North Pole deposits. These waters would have had to have circulated into the volcanic pile and been extensively reduced at elevated temperatures, as is envisaged in the generation of post-Archean volcanogenic mineralisation from seawater-rich fluids (e.g. Ohmoto and Rye, 1979). However, the geological evidence favour a restricted basin for the North Pole sequence (e.g. Groves et al., 1981) so, there is no evidence for the world-wide abundance of sulfate at this early stage of Earth history. Outside the east Pilbara and Barberton regions the only indications of Archean sedimentary or exhalative sulfate minerals known to the author are ankerite, which may be pseudomorphing gypsum in the ca. $2.7 \mathrm{Ga}$ Black Flag Beds at Kalgoorlie, Western Australia (Golding and Walter, 1979), barite mineralization in the Peninsula Gneiss Complex of India (Radhakrishna and Vasudev, 1977), and minor barite in the Kidd Creek deposit of Canada (W. Brook, per. comm. 1978). Sulfates in metasomatised carbonates in the Aldan Shield (e.g. Vinogradov et al., 1976) may have formed from sedimentary sulfates.

The isotopic fractionations between oxidised and reduced sulfur species in hydrothermal and biological systems (e.g. Ohmoto and Rye, 1979) mean that the $\delta^{34} S$ values for sedimentary and volcanogenic sulfides should have concentrated around $0 \%$ only as long as there was no significant concentration of $\mathrm{SO}_{4}^{2-}$ in the hydrosphere as a whole. Therefore, the observation that the great bulk of the $\delta^{34} \mathrm{~S}$ results for such sulfides from various Archean sequences are in the range $0 \pm 4 \%$, is evidence against moderate to high concentrations of $\mathrm{SO}_{4}^{2-}$ in the hydrosphere (e.g. Lambert, 1978; Cameron, 1982; Skyring and Donnelly, 1982). A small proportion of the $\delta^{34} \mathrm{~S}$ results for Archean sulfides are outside this range, in accord with the presence of minor $\mathrm{SO}_{4}^{2-}$; these are best documented from some ca. $2.7 \mathrm{Ga}$ Canadian iron formations (Goodwin et al., 1976), and also reported from some volcanogenic deposits (Seccombe, 1977; Menon et al., 1982). In a study of sulfides in sedimentary strata from a variety of stratigraphic levels in Archean and Proterozoic sequences of South Africa, Cameron (1982) found a $\delta^{34} \mathrm{~S}$ transition from near $0 \%$ in strata older than about $2.35 \mathrm{Ga}$, to significantly negative and positive values in younger rocks. Further evidence for a major increase in the concentrations of $\mathrm{SO}_{4}^{2-}$ in the hydrosphere in the Lower Proterozoic is provided by pseudomorphed sulfate-evaporite deposits in the Great Slave Lake area of Canada (Badham- and Stanworth, 1977) and the Pine Creek Geosyncline (Crick and Muir, 1980).

The Great Slave Lake sequence also contains pseudomorphs after bedded halite (Badham and Stanworth, 1977). There are no reports of older halite deposits than this, suggesting that the chloride concentrations of the hydrosphere built up slowly during the Archean.

ARCHEAN LIFE Following the pioneering experiments of Miller (1953), there have been many laboratory syntheses of amino-acids and other simple organic compounds, driven by a variety of energy sources (e.g. Calvin, 1969). A further step in the sequence of events leading to life was achieved with the laboratory syntesis of "primitive protein" (high molecular weight organic polymers) and "protocells" (primitive organized structures) using thermal energy (Fox, 1971).

Hoyle and Wickramasinghe (1977) speculated that the low molecular weight organic compounds and radicals found in interstellar clouds are the result of radiation degradation of much more complex organic molecules, which they believe could have been added to the primitive Earth. The addition of extraterrestrial organic compounds, after solidification of the proto-crust, may have complemented terrestrial abiotic syntheses of the building blocks of life.

The main environments have been proposed for evolution of prebiotic compounds to living systems:

(i) Solar energy acting on a marine dilute organic "soup" (Haldane, 1929; Oparin, 1957).

(ii) Alternation of hot, dry conditions and cold damp conditions in desert environments (Orgel, 1974).

(iii) Terrestrial energy. (heat) in active volcanic areas (Sylvester-Bradley, 1975; Degens, 1977; Corliss et al., 1981).

Of these, the third seems most appropriate to the early Archean record. Corliss et al. (1981) consider that various reduced gases and organic molecules were generated by reactions in seawater which extracted heat and $\mathrm{CO}_{2}$ from magmas entering the submarine crust, with saponite-coated fracture surfaces catalysing the reactions. With the prolific igneous activity in the early Earth, "protocells" could have been generated in many submarine volcanic environments, and, by chance, life forms could have evolved in a small number of them. Abiotic synthesis of organisms probably occurred locally at different places, with multiple origins, evolutions and extinctions of primitive forms.

In the past decade, there has been a concentrated effort put into locating evidence of life in ancient rocks. The two main approaches have been searches for microfossils stromatolites and stable isotopic studies.

Pflug and Jaeschke-Boyer (1979) described "yeast-like microfossils" in amphibolite facies metaquartzites from the $3.8 \mathrm{Ga}$ Isua supracrustals, Schidlowski et al. (1979) found average $\delta^{13} \mathrm{C}$ values of $-2.5 \%$ for carbonate and $-15.3 \%$ for carbonate and graphitic carbon in the Isua metasediments, with the results displaying considerable scatter. They interpreted these data in terms of metamorphic modifica- 
tion of the "modern" biologically-controlled partitioning of carbon between reduced and oxidised species, which typically yields $\delta^{13} \mathrm{C}$ values of close to $0 \%$ and $-25 \%$ for carbonate and reduced carbon, respectively. This led them to conclude that there was an extremely early (pre-3.8Ga) origin of life and photosynthetic activity on Earth, and that the terrestrial carbon cycle was virtually stabilised at the time of accumulation of $_{\text {of }}$ the Isua strata.

However, these conclusions are disputable. The considerable metamorphism and deformation render it unlikely that microfossils would be preserved in the Isua rocks, and the "microfossil-like" objects of Pflug and Jaeschke-Boyer (op. cit.) have been reinterpreted as limonite-stained fluid inclusions by Bridgwater el al. (1981), and iron-oxide stained weathering pits after small siderite crystals by E. Roedder (per. comm. 1982). Amino-acids and hydrocarbons in the Isua rocks have been shown by Nagy et al. (1981) to include geologically unstable compounds, implying recent diffusion of biochemicals from encrusting lichens. Finally, the carbon isotopic compositions of the Isua rocks could have formed by inorganic processes in hydrothermal systems, with varying degrees of conversion of methane to carbon. Therefore, there is no compelling evidence for the existence of life at the time the Isua supracrustals were formed.

Putative microfossils have been reported from sub-greenschist facies, $3.5 \mathrm{Ga}$ cherts interbedded with barite at North Pole, Western Australia (Dunlop et al., 1978; Awramik et al., 1982), and from the Onverwacht Group of South Africa (Muir and Grant, 1976); furthermore, Lowe (1980) and Walter et al. (1980)/have described stromatolites in cherts from the North Pole region. Schopf and Walter (1982) have assessed the authenticity of these and other reports of Archean "fossils". They concluded that only two geological units in the Archean - the bedded stromatolitic cherts at North Pole, and cherty stromatolitic limestones of the ca. $2.8 \mathrm{Ga}$ Fortescue Group of the Hamersley Basin, also in Western Australia - contain well established Archean microbiotas. They categorise the microstructures described from the Onverwacht and Fig Tree Groups of South Africa as possible microfossils ("dubiomicrofossils"). Thus the Archean fossil record remains very poorly known. In contrast, stromatolites were an abundant component of the sedimentary environment at least as early as $2.8 \mathrm{Ga}$ (Walter, 1982).

The most detailed studies by far have been conducted on the North Pole microfossils. Their morphologies, distribution and physical organisation, and kerogen geochemistry led Schopf and Walter (op. cit.) to infer that some of the organisms there were photo-responsive, at least some were anaerobes, some were autotrophs (organisms that used $\mathrm{CO}_{2}$ as their immediate source of cellular carbon), and that organic carbon was probably recycled within the microbial mats by heterotrophic microorganisms (dependent on organic nutrients); there are no data indicating whether the presumed photo-autotrophs were oxygen producing. The Archean stromatolite record (Walter, 1982) provides further evidence for autotrophy, response to light, and gliding.

Schidlowski et al. (1982) considered the isotopic inferences of ancient biochemistries. They concluded that the carbon isotopic compositions of kerogen and carbonate in sedimentary strata $\leq 3.5 \mathrm{Ga}$ are essentially constant and indicate biological (photosynthetic) activity. They believe local excursions of $\delta^{13} \mathrm{C}$ values for kerogens to very low values $(-40 \%$ to $50 \%)$ are suggestive of methane utilising pathways in the formation of the kerogen precursors.
It was concluded in the previous section that sulfur isotopic and mineralogical data currently available do not favour the build up of $\mathrm{SO}_{4}^{2-}$ levels in the hydrosphere as a whole, until the Lower Proterozoic. As sulphurous exhalation must have been entering the hydrosphere in abundance throughout the Archean, it is difficult to see how an oxygenous atmosphere could have developed without a preceding period of major oxidation of reduced sulfur species in the hydrosphere. Therefore, I consider that the sulfur-isotope data, complement the various lines of evidence put forward by Cloud (e.g. 1974, 1976) which, although not unequivocal (e.g. Clemmey and Badham, 1982) are all consistent with the advent of an oxygenous atmosphere in the Lower Proterozoic. This in no way precludes oxygen production during the Archean, either by photosynthesis in at least local environments or by photodissociation. Such oxygen could have been used up in oxidising reactions within the hydro. sphere/atmosphere system. It was possibly important in producing high sulfate concentrations at North Pole and the South African barite forming environments, but these could also have been achieved by the actions of photosyn. thetic sulfur bacteria; where iron was available any free oxygen should have reacted with it to form iron oxides.

A general build up of $\mathrm{SO}_{4}^{2--}$ is likely to have preceded the proliferation of sulfate-reducing bacteria. The wide range of $\delta^{34} \mathrm{~S}$ values in sulfide facies iron-formation in southern Canada has been cited as the earliest evidence for bacterial sulfate reduction (Goodwin et al., 1976; Schidlowski et al., 1982). Whilst this may be so, it is not yet proven because these deposits could well have formed as a result of hydrothermal activity, which can also lead to major sulfur isotope fractions if $\mathrm{SO}_{4}^{2-}$ is a component of the fluids (e.g. Ohmoto and Rye, 1979). Skyring and Donnelly (1982) speculated that sulfite from minor proportions of ${ }^{34} \mathrm{~S}$-enriched $\mathrm{SO}_{2}$ in exhalations was the most readily available $S$-source to evolving organisms, and that bacterial sulfite reduction preceded dissimilatory sulfate reduction, which they consider to have become an important process in the S-cycle in the Lower .Proterozoic.

SUMMARY AND CONCLUSIONS Even the maximum temperatures estimated to have been generated in the Earth during accretion and core formation would have caused melting only above a depth of ca. $400 \mathrm{~km}$. Cooling and fractionation of the outer melted zone should have. formed a predominantly simatic proto-crust, some 30 to $100 \mathrm{~km}$ thick which contained much less granitic material than the present crust. Major impacting events probably caused brecciation, fracturing, more melting and exhalative activity before $c a, 3,9 \mathrm{Ga}$. The proto-mantle would have comprised olivine-rich cumulates and depleted peridotite, grading into undepleted peridotite.

Sialic components were added to the crust during the Archean; tonalitic and trondhjemitic granitoids would have formed largely by anatexis of simatic proto-crust, and potassic granites from anatexis involving earlier-formed, plagioclase-rich granitoids. Archean greenstone sequences reflect major mantle melting events at various times during the Archean, and they probably accumulated in different environments at different stages of crustal evolution. Dense residual rocks from simatic anatexis probably sank into the mantle, effectively completing the transformation from a predominantly simatic proto-crust to a granitoid-rich stable crust. 
The primitive atmosphere/hydrosphere system developed largely as a result of degassing of the Earth. The earliest atmosphere probably consisted mainly of $\mathrm{H}_{2} \mathrm{O}, \mathrm{CO}_{2}$, with lesser amounts of $\mathrm{CO}, \mathrm{N}_{2}, \mathrm{H}_{2}, \mathrm{H}_{2} \mathrm{~S}, \mathrm{SO}_{2}, \mathrm{HCl}$, and possibly some $\mathrm{NH}_{3}$ and $\mathrm{CH}_{4}$. There was no juvenile source of $\mathrm{O}_{2}$, and sulfur isotope data support other lines of evidence that an oxygenated atmosphere did not evolve until the Lower Proterozoic. The Archean hydrosphere probably had a low $\mathrm{NaCl}$ content, but degassing probably resulted in it being enriched in iron, silica and carbonate species. Abiotic synthesis of organic compounds leading eventually to life probably occurred before $3.5 \mathrm{Ga}$, on the basis of microfossil, stromatolite and carbon isotope data. Microbial photosynthesis was probably widespread in Archean marginal marine environments, but there is no compelling evidence that dissimilatory sulphate reducing bacteria proliferated before the Lower Proterozoic.

Acknowledgements The Bass Becking Laboratory is supported by the Australian Mineral Industries Research Association Ltd., the Bureau of Mineral Resources and the Commonwealth Scientific and Industrial Research Organization. The author's ideas have benefitted from various discussions of early Earth history with T.H. Donnelly, A.Y. Glikson, D.I. Groves, A.E. Ringwood, G.W. Skyring, P.A. Trudinger, and M.R. Walter. Dr. Walter is also thanked for his critical appraisal of a draft of this paper.

\section{REFERENCES}

ALLAART, J.H. - 1976 - The pre-3760 m.y. old supracrustal rocks of the Isua area, central wes! Greenland, and the associated occurrence of quartz-banded ironstone. In: B.F. Windtey (ed.). The Early History of the Earth. Wyley, London: pp. 177.190.

ARNDT, N.T. - 1977 - Ultrabasic magmas and high degree melting of the mantle, Contrib. Mineral. Petrol. 64:205-222.

ARTH, J.G., ARNDT, N.T, and NALDRETT, A.J. - 1977 - Genesis of Archean komatiites-trace element evidence from Munro Township. Geology 5:590-594

ASHENDORF, D. - 1980 - Are sulfur isotope ratios sufficient to deter mine the antiquity of sulfate reduction? Origins Life 10:325-333.

AWRAMIK, S.M., SCHOPF, J.W. and WALTER, M.R. - Filamentous fossil bacteria from the Archaean of Western Australia. Submitted to Precamb. Res.

BADHAM, J.P.N and STANWORTH, C.W - 1977 - Evaporites from the Lower Proterozoic of the east arm, Great Slave Lake. Nature 268:5 ! 6 -517 .

BICKLE, M.J., HAWKESWORTH, C.J., MARTIN, A., NISBET, E.G. and O'NIONS, R.K. - 1976 - Mantle compositions derived from the chemistry of ultramafic lavas. Nature 263:577-580.

BRIDGWATER, D, ef al, - 1981 - Microfossil-like objects from the Archaean of Greenland: a cautionary note. Nature 289:51-53.

BROWN, H. - 1952 - Rare gases and the formation of the Earth's atmosphere. In: G. Kuiper (ed.), Atmospheres of the Earth and Planets. Univ. Chicago Press, 2nd edition, pp. 258-266.

CALVIN, M. $-1969-$ Chemical Evolution. Oxford Univ. Press

CAMERON, E.M. - 1982 - Sulphate and sulphate reduction in early Precambrian oceans. Nature $296: 145-148$

CAMERON, E.M. and GARRELS. R.M. - 1980 - Geochemical compositions of some Precambrian shales from the Canadian shield. Chem. Geol. 28:181-197.

CLEMMEY, $\mathrm{H}$, and BADHAM J P.N, $-1982-$ Oxygen in the Precambrian atmosphere: an evaluation of the geological evidence. Geology 10:141-146

CLOUD, P. - 1974 - Almosphere, development of Encyclopaedia Britannica, 15th edition, pp. 313.319.

CLOUD, P. - 1976 - Major features of crustal evolution. Geol. Soc. S Afr., Spec. Publ., 79 (annex):1-32

COLLERSON, K.D., KERR, A. and COMPSTON, W. $-1981-$ Geochronology and evolution of late Archaean gneisses in northern Labrador: an example of reworked sialic crust. Spec. Publ, 7, Geol. Soc. Austral: $313-328$

CONDIE, K.C. - 1981 - Geochemical and isotopic constraints on the origin and source of Archaean granites. Spec. Publ. 7, Geol. Soc, Austral: 469-480.

CORLISS, J.B., BAROSS, J.A. and HOFFMAN, S.E. - $\{98\}$ - An hypo. thesis concerning the relationship between submarine hot springs and origin of Jife on Earth. Oceanologica Acta. Colloque 4, Geology of Oceans pp. $59-69$.

COSTA, U.R, FYFE, W.S., KERRICH, R, and NESBITT, H.W. - $1980-$ Archaean hydrothermal talc and evidence for high ocean temperatures. Chem. Geol. 30:341-349.

COSTA, U.R., FYFE, W.S., KERRICH, R. and NESBITT, H.W. - 1981Is ocean formation synchronous with the first preservation of crust? Spec. Publ. 7, Geol. Soc. Austral:453-456.

CRICK, J.H. and MUIR, M.D. - $1980-$ Evaporites and uranium mineralization in the Pine Creek Geosyncline. $I n$ : J. Ferguson and A. Goleby (eds.), Uranium in the Pine Creek Geosyncline. Int. Atomic Energy Agency, Vienna, pp. 531.542.
DEGENS, E.T. - 1979 - Primordial synthesis of organic matter. In: B Bolin, et al. (eds.), The Global Carbon Cycle. John Wiley and Sons.

DUNLOP, J.S.R. - 1978 - Shallow water sedimentation at North Pole Pilbara Block, Western Australia. In: J.E. Glover, and D.I. Groves (eds.), Archaean Cherty Metasediments. Geol. Dept and Extension Service, Univ. W. Australia, pp. 30-38.

DUNLOP, J.S.R. and GROVES, D.I. - 1978 - Sedimentary barite of the Barberton Mountain Land: a brief review. In: J.E. Glover, and D.I Groves (eds.), Archaean Cherty Metasediments. Geol. Dept and Extension Service, Univ. W, Australia, pp. 39-44

DUNLOP, J.S.R., MUIR, M.D., MILNE, V.A. and GROVES, D.I - 1978 - A new microfossil assemblage from the Archaean of Western Australia. Nature 274:676-678.

FANALE, F.P. - 1971 - A case for catastrophic early degassing of the Earth. Chem: Geol. $271: 521-536$.

FOX, S.W. - 1971 - Self assembiy of the protocell from a self ordered polymer. In: A.P. Kimball and J. Oro (eds.), Prebiotic and Biochemical Evolution. North Holland Publ. Co., Amsterdam.

GLIKSON, A.Y. - $\{976$-- Earliest Precambrian ultramafic-mafic volcanic rocks ancient oceanic crust or relic terrestrial maria. Geology 4:202-205.

GLJKSON, A.Y. and LAMBERT, I.B. - 1976 - Vertical zonation and petrogenesis of the early Precambrian crust in Western Australia. Tectonophysics $\mathbf{3 0}: 55-89$.

GOLDING, L.Y. and WALTER, M.R. - 1979 - Evidence of evaporite minerals in the Archaean Black Flag Beds, Kalgoorlie, Western Australia. BMR Journ. Austral. Geol. Geophys. 4:67-71.

GOODWIN, A.M. - 1976-Giant impacting and the development of continental crust. In: B.F. Windley (ed.), The Early History of the Earth. Wiley, London, pp. 77-95.

GOODWIN, A.M., MONSTER, J. and THODE, H.G. - 1976 - Carbon and sulfur isotope abundances in Archean iron formations and early Precambrian life. Econ. Geol. 71:870-892.

GREEN, D.H. - 1972 - Archacan greenstone belts may include terrestrial equivalents of lunar maria. Earth Planet. Sci. Lett. 15:263-270.

GREEN, D.H. - 1976a - Experimental petrology in Australia - a review. Earth Sci. Rev. 12:99-138.

GREEN, D.H. - $1976 b$ - Experimental testing of "equilibrium" partial melting of peridotite under water-saturated, high pressure conditions. Can. Mineral. 14:255-268.

GROVES, D.I., DUNLOP, J.S.R. and BUICK, R, -1981 - An early habitat of life. Scient. American 245:64-73.

HALDANE, -J.B.S - 1929 - The origin of life, Rationalist Annuat (reprinted in J.D. Bernal, 1967 - The Origins of Life. Weidenfeld and Nicholson, London).

HAMILTON, P.J., O'NIONS, R.K. EVENSEN, N.M, BRIDGWATER D. and ALLAART, J.H. - 1978 - Sm-Nd isotopic investigations of Isua supracrustals and implications for mantle evolution. Nature $272: 41-43$.

HANKS, T.C. and ANDERSON, D.L. - $1969-$ The early thermal history of the Earth. Phys. Earth, Planet. Inter., 2:19-29.

HEINRICHS, T.K. and REIMER, T.O. -1977 - A sedimentary barite deposit from the Archaean Fig. Tree Group of the Barberton Mountain Land (South Africa). Econ. Geol. 72:1426-1441.

HOLLAND, H.D. - 1972 - The geologic history of seawater - an attempt to solve the problem. Geochim. Cosmochim. Acta 36:637-651.

HOLLAND, H.D -1976 - The evolution of seawater. In: B.F. Windley (ed.), The Early History of the Earth. Wiley, London, pp. \$59-568.

HOYLE, F. and WICKRAMASINGHE, N.C. - 1977 - Origin and nature of carbonaceous material in the galaxy. Nature 270:701 703. 
KNAUTH, L.P. and LOWE, D.R. - 1978 - Oxygen isotope geochemistry of cherts from the Onverwacht Group (3.4 billion years), Transvaal, South Africa, with implications for secular variations in the isotope compositions of cherts. Earth Planet. Sci. Lett. 41:209-222.

LAMBERT, I.B. - 1978-Sulphur isotope investigations of Archaean mineralisation and some implications concerning geobiochemical evolution. In: J.E. Glover, and D.I. Groves (eds.), Archaean Cherty Metasediments, Geol. Dept and Extension Service, Univ. W. Australia, pp. 45-56.

LAMBERT, I.B., DONNELLY, T.H., DUNLOP, J.S.R. and GROVES, D.I. - 1978 - Stable isotopic compositions of early Archaean sulphate deposits of probable evaporitic and volcanogenic origins. Nature 276:808-811.

LAMBERT, 1.B. and GROVES, D.I. - 1978 - Early Earth evolution and metallogeny. $m:$ K.H. Wolf (ed.), Handbook of Strata-Bound and Stratiform Ore Deposits. Elsevier, Amsterdam, 8:339-447.

LAMBERT, 1.B. and WYLLIE, P.J. - 1972 - Melting of gabbro (quartz eclogite) with excess water to 35 kilobars, with geological implications. J. Geol. 80:693-708.

LAMBERT, I.B. and WYLLIE, P.J. - $1974-$ Melting of tonalite and crystallisation of andesite liquid with excess water to 30 kilobars. J. Geol. $82: 88-97$.

LOWE, D.R. $-1980-$ Stromatolites 3400 Myr old from the Archaean of Western Australia. Nature 284:441-443.

McCALL, G.J.H. - 1981 - Progress in research into the early history of the Earth: A review 1970-1980. Spec. Publ. 7, Geol. Soc. Austral, pp. 3-18.

McGREGOR, V.M. - 1973 - The early Precambrian gneisses of the Gothaab district, west Greenland. Philos. Trans. R. Soc. London, Ser. A, 273:343-358

MENON, A.G., VENKATASUBRAMANIAN, V.S, and ANANTHA IYER, G.V. - 1982 - Sulfur isotope abundance variations in sulphides of the Dharwar Craton. Indo-U.S. Workshop on Precambrians of south India. Abstracts: 37.

MILLER, S.L. - 1953 - A production of amino-acids under possible primitive Earth conditions. Science 117:528-529.

MOORBATH, S., ALLAART, J.H., BRIDGWATER, D. and McGREGOR, V.M. - 1977 - Rb-Sr ages of early Archaean supracrustal rocks and Amitsoq gneisses at Isua, Nature 270:43n45.

MUIR, M.D. and GRANT, P.R. - 1976- Micropaleontological evidence from the Onverwacht Group, South Africa. In: B.F. Windley (ed.), The Early History of the Earth. Wiley, London, pp. 595-604.

MYSEN, B.O. and BOETTCHER, A.L. - 1972 - Melting in a hydrous mantle: phase relationships in peridotite $-\mathrm{H}_{2} \mathrm{O}-\mathrm{CO}_{2}$ systems. Program Ann. Med. Geol. Soc. Am., p. 608.

NAGY, B., ENGEL, M.H., ZUMBERGE, J.E., OGINO, H. and CHANG, SAI Y. -1981 - Amino-acids and hydrocarbons $\sim 3800-\mathrm{Myr}$ old in the Isua rocks, southwestern Greenland. Nature 289:53-56.

NICHOLLS, I.A. and RINGWOOD, A.E. - 1972-Effect of water on olivine stability in tholeites and the production of silica-saturated magmas in the island arc environment. $J$. Geol, 81:285-300.

NICHOLLS, I.A. and RINGWOOD, A.E. - 1974-A possible mantle origin for andesitic magmas: Discussion. Earth Planet. Sci, Lett. $21: 221$ -229 .

OHMOTO, H. and RYE, R.O. - 1979 - Isotopes of sulfur and carbon. In: H.L. Barnes (ed.), Hydrothermal Ore Deposits, 2:509-567.

O'NIONS, R.K. and PANKHURST, R.J. -1978 - Early Archaean rocks and geochemical evolution of the Earth's crust. Earth Planet. Sci. Lett. $38: 211-236$,

OPARIN, A.l. - 1957 - The Origin of Life on Earth. Oliver and Boyd, London, 3rd edition.

ORGEL, L.E. $-1974-$ The synthesis of life molecules. In: J.P. Wild (ed.), In the Beginning. .. the Origin of Planets and Life. Austral. Acad. Sci. Canberra, pp. 85-101.

OVERSBY, V.M. and RINGWOOD, A.E. - 1971 - Time of formation of the Earth's core, Nature 234:463-465.

PERRY, E.C., MONSTER, J. and REIMER, T. - 1971 - Sulphur isotopes in Swaziland System barites and the evolution of the Earth's atmosphere. Science 171:1015-1016.

PFLUG, H.D. and JAESCHKE-BOYER, H. - 1979 - Combined structural and chemical analysis of $3,800-\mathrm{Myr}$-old microfossils. Nature 280-483-486.
RADHAKRISHNA, B.P. and VASUDEV, V.N. - 1977 - The early Precambrian of the southern Indian shield. J. Geol. Soc. India 18:525-554.

RINGWOOD, A.E. - 1975 - Compositirn and Petrology of the Earth's Mantle. McGraw-Hill, New York.

RINGWOOD, A.E. - $1977 a-$ Composition of the core and implications for origin of the Earth. Geochem. $j$. 11:111-135.

RINGWOOD, A.E. - 1979 - Origin of the Earth and Moon. Springer-Verlag, New York.

RUBEY, W.W. - 1951 - Geologic history of seawater. Geol. Soc. Am. Bull. 62:1111-1147.

SCHIDLOWSKI, M., APPEL, P.W.U., EICHMANN, R. and JUNGE, C.E. -1979 - Carbon isotope geochemistry of the $3.7 \times 10^{9}$-yr-old Isua sediments, west Greenland: implications for the Archacan carbon and oxygen cycles. Geochim. Cosmochim. Acta 43:189-199.

SCHIDLOWSKI, M., HAYES, J.M. and KAPLAN, I.R. - Isotopic inferences of ancient biochemistries. In: J.W. Schopf (ed.), The Earth's Earliest Biosphere: Its Origin and Evolution. Princeton Univ. Press (in press).

SCHOPF, J.W, and WALTER, M.R. - Archean microfossils : new evidence of ancient microbes. In: J.W. Schopf (ed.), The Earth's Earliest Biosphere: Its Origin and Evolution. Princeton Univ. Press (in press).

SECCOMBË, P.K. - 1977 - Sulfur isotope and trace metal composition of stratiform sulfides as an ore guide in the Canadian shield. $J$. Geochem. Explor. 8:117-137.

SHAW, D.M. -1972 - The development of the early continental crust Part 1: Use of trace element distribution coefficient models for the Protoarchaean crust. Can. J. Earth Sci. 9:1577-1595.

SHAW, D.M. - 1976 - Development of the early continental crust. Part 2 : Prearchaean, Protoarchaean and later eras. In: B.F. Windley, (ed.), The Early History of the Earth. Wiley, London, pp. 33-54.

SKYRING, G.W. and DONNELLY, T.H. - 1982 - Precambrian sulfur isotopes and a possible role for sulfite in the evolution of biological sulfate reduction. Precamb. Res. 17:41-61.

SMITH, J.V. - 1976 - Development of the Earth-Moon system with implications for the geology of the early Earth. $I n$; B.F. Windley (ed.), The Early History of the Earth. Wiley, London, pp. 3-20.

SUN, S-S. and NESBITT, R.W. - 1978 - Petrogenesis of Archaean ultrabasic and basic volcanics: evidence from rare earth elements. Comirib. Mineral. Petrol, 65:301-325.

SYLVESTER-BRADLEY, P.C. - $\$ 976$ - Evolutionary oscillations in prebiology: igneous activity and the origins of life. Origins Life 7:9-18.

TAYLOR, S.R. and MCLENNAN, S.M. - 1981 - Evidence from rare-earth elements for the chemical composition of the Archaean crust Spec. Publ. 7, Geol. Soc. Aust., pp. 255-262

VEIZER, J. - 1982 - Mantle buffering of the early oceans. Nalurwissenschaften 69:173-180.

VEIZER, J. and HOEFS, J. - 1976 - The nature of $\mathrm{O}^{18} / \mathrm{O}^{16}$ and $\mathrm{C}^{13} / \mathrm{C}^{12}$ secular trends in sedimentary carbonate rocks. Geochim. Cosmochim. Acta 40:1387-1395.

VINOGRADOV, V.I., REIMER, T.O., LEITES, A.M. and SMELON S.B. - 1976 - The oldest sulfates in the Archean formations of the South African and Aldan shields, and the evolution of the Earths oxygen atmosphere. Lithol. Miner. Resour. 11:407-420.

VOLLMER, R. - 1977 - Terrestrial lead isotopic evolution and formation time of the Earth's core. Nature 270:144 147.

WALKER, J.C.G. - 1976a-Implications for atmospheric evolution of the inhomogeneous accretion model of the origin of the Earth. $m:$ B.F. Windley (ed.), The Early Origin of the Earth. Wiley, London, pp. 536-546.

WALKER, J.C.G. - 1976b-Evolution of the Atmosphere. Hafner, New York.

WALTER, M.R. - Archean stromatolites: evidence of the Earth's eartiest benthos. In: J.W. Schopf (ed.), The Earth's Earliest Biosphere: Its Origin and Evolution. Princeton Univ. Press (in press).

WALTER, M.R, BUICK, R. and DUNLOP, J.S.R. - 1980 - Stromatolites $3,400 \times 3,500 \mathrm{Myr}$ old from the North Pole area, Western Australia, Nature $284: 443-445$.

WYLLIE, P.J. - 1971 - The Dynamic Earth. Wiley, New York.

Recebjido em 10 de setembro de 1982 